\title{
The Use of Mulberry (Morus alba) Extract in the Mass Production of Blue Swimming Crab (Portunus pelagicus L.) Larvae to Overcome the Mortality Rate Due to Molting Syndrome
}

\author{
Yushinta Fujaya \\ Department of Fisheries, Faculty of Marine and Fisheries Science, Hasanuddin University \\ Makassar 90245, Indonesia \\ E-mail: fyushinta@yahoo.com
}

Dody Dharmawan Trijuno

Department of Fisheries, Faculty of Marine and Fisheries Science, Hasanuddin University

Makassar 90245, Indonesia

Andi Nikhlani

Department of Fisheries, Faculty of Marine and Fisheries Science, Mulawarman University

Samarinda 1068, Indonesia

Indra Cahyono

BAKIKDIWA Institute of Marine Science and Technology

Makassar 90245, Indonesia

\author{
Hasnidar \\ Department of Fisheries, Faculty of Fisheries and Marine Science \\ Indonesian of Moslem University \\ Makassar 90245, Indonesia
}




\title{
Macrothink
}

Received: May 7, 2013 Accepted: June 30, 2013 Published: January 1, 2014

doi:10.5296/ast.v2i1.4048ＵRL: http://dx.doi.org/10.5296/ast.v2i1.4048

\begin{abstract}
One of the problems in blue swimming crab seedling is the high rate of mortality. This study is aimed at analyzing the influence of mulberry extract (ME) on the survival rate of crab larvae which are managed to metamorphose to the next stage and on the rate of larval development, as well as identifying various factors causing mortality in the mass cultured larvae, mainly mortality caused by molting syndrome. There are 4 treatments of different doses of mulberry extract being tested which are: $0 \mathrm{mg} / 100 \mathrm{~g}$ (control), $1 \mathrm{mg} / 100 \mathrm{~g}, 2 \mathrm{mg} / 100$ $\mathrm{g}$, and $4 \mathrm{mg} / 100 \mathrm{~g}$. Mulberry extract is given through feeding since day- 8 of the stocking, which is the time when larvae enter zoea 3 . The rearing process is done over 19 days in a concrete tank with a volume of 1 ton with the initial number of zoea at \pm 350.000 . The findings show that mulberry extract has a significant influence on the survival rate, stage growth, and the mortality rate of blue swimming crab larvae due to molting syndrome. The higher the dose of ME in the artificial food, the higher the survival rate and the lower the mortality rate due to molting syndrome. The treatment with $4 \mathrm{mg}$ of mulberry extract/100 mg is the only treatment which successfully enters megaloph and crab stage. Control treatment and the dose of $1 \mathrm{mg} / 100 \mathrm{~g}$ can only reach zoea 3 while the dose of $2 \mathrm{mg} / 100 \mathrm{~g}$ can only reach zoea 4 . This study shows that the total mortality rate is still high, but it is found that the main cause is not molting syndrome. Mortality rate due to molting syndrome in the treatment of the dose of $4 \mathrm{mg}$ of mulberry extract is only $\pm 15.61 \%$ of the total larval mortality. The unidentified factors dominate the cause of mortality $( \pm 57.47 \%)$. Other factors are fungal attack $( \pm 17.65 \%)$, morphological disorder $( \pm 9.28 \%)$, and cannibalism $( \pm 14.93 \%)$.
\end{abstract}

Keywords: Mulberry (Morus alba), Metamorphoses, Mortality, Blue Swimming Crab (Portunus pelagicus L.), Larvae 


\section{Introduction}

Portunus pelagicus L. is one of the commercial crabs traded widely around the world. In Indonesia, the crab species is under intensive development to meet the increasing overseas market demand. The export volume reaches 23 to 25 million tons per year. The increasing amount of crab fishing caused decrease in natural populations, in both quantity and quality. FAO (2011) in World Bank (2012) mentioned that in 2008, Indonesia contributed $20 \%$ of the world blue swimming crab production and ranked second of the biggest producer after China. Unfortunately, along with the increase of human needs and pressure on the marine biological resources environment, the live stock of crabs in Indonesia is continually decreasing by 20 30\% each year (Mahesa, 2010). Therefore, other methods to increase crab the supply of crab raw material is highly needed, for example through culture.

The blue swimming crab can be cultured in ponds but the seeds still rely on the catch from natural habitat so this action is still potential to press the natural population. Attempts to culture them using seeds from hatchery is still being studied, and have not yet carried out in mass production. One of the causes is that blue swimming crab seedling in hatchery has not given any consistent result yet. The survival rate of seeds usually fluctuates and is generally low. Maheswarudu (2008) reported that the highest survival rate (10.3 $\pm 5.76 \%)$ from zoea-1 to Crab-1 is achieved in low density stocking (50 larvae/liter). Moreover, Juwana et al., (2010) was successful in increasing the survival rate from $2.2 \%$ to $8.7 \%$ through probiotic administration. Zmora et al., in 2005 then reported that cannibalism is one the factors causing high mortality, so it is suggested to use the shelter and size grading, and decrease stock density.

The main problem in the blue swimming crab seedling is mortality (Soundarapandian et al., 2008). Mortality is caused by various factors, such as disease attack (Govindasamy \& Srinivasan, 2012; Talpur et al., 2011a; Talpur et al., 2011b), molting syndrome (Hamasaki et al., 2002 and cannibalism (Soundarapandian et al., 2008). Many ways have been done to overcome those problems, such as nutrition enrichment of natural food using HUFA to increase EPA and DHA in order to increase larval resistance (Hamasaki et al., 2002; Samuel et al., 2011) by using probiotic to control the pathogenic bacterial attack, Vibrio (Juwana et al., 2010), adjusting the amount and feeding time of natural food (Ikhwanuddin et al., 2012; Redzuari et al., 2012), using shelter and size grading, and reducing stock to reduce cannibalism (Zmora et al., 2005). Nevertheless, litte investigation has focused on the control on molting syndrome through hormonal regulation controlling molting syndrome in crab larvae.

In arthropods and crustaceans, hormone regulating molting is ecdysteroid (Huberman, 2000). ecdysteroid controls ecdysis (molting) and metamorphosis. Molting is a process of skin change which enables larvae to develop and metamorphose from zoea 1-4 phase to megaloph and crab. The increase of ecdysteroid in the circulation will stimulate molting; conversely, the decrease of ecdysteroid will stimulate the release of hormone inhibiting molting (Lockwood, 1967).

The use of exogen hormone to increase hormone titer in vivo has been widely used in the 
high class of animals and humans. However, little effort of this kind has been done in crabs. Azra et al., (2012) used 20-Hydroxyecdysone exogen added into the rearing of $P$. pelagicus larvae to stimulate molting. Phytoecdysteroid of spinach (Amaranthaceae) has also been used to stimulate molting in the production of soft-shell crabs (Aslamyah \& Fujaya, 2010; Fujaya, 2011; Fujaya et al., 2011).

Phytoecdysteroid has an analogous structure with growth hormone of insects and some other invertebrates such as crustaceans (Feldman, 2009). Phytoecdysteroid is produced by some species of plants for self-defense against insectal attacks (Schmelz et al., 2002) and nematodes (Soriano et al., 2004). One of the plants producing phytoecdysteroid is mulberry (Morus sp). This plant produces phytoecdysteroid and has long been used as food in silkworm cultivation (Nguku et al., 2007). Phytoecdysteroid contained in the Moraceae and Amaranthaceae plants is analogous with ecdysteroid contained in crabs (Callinectes sapidus), so Ecdybase names it Inokosterone (Callinecdysone A).

This study is aimed to analyzing the influence of mulberry extract (ME) on the survival rate of the blue swimming crab larvae which are managed to metamorphose to the next stage and on the rate of larval development, as well as identifying various factors causing mortality of mass cultured larvae, mainly mortality caused by molting syndrome. The application of $\mathrm{ME}$ is expected to be able to successfully stimulate and cause molting simultaneously in the stage change so mortality rate can be decreased.

\section{Material and Method of Study}

\subsection{Broodstock of Crabs}

Broodstock used in this study are caught from the sea around Pangkep- Barru waters, South Sulawesi. Next, broodstock of the crabs are brought to home scale hatchery (backyard) in Palie village, Takkalasi district, Barru regency. Every broodstock of the crabs that have contained black eggs is placed in a concrete tank with a capacity of 1 ton to hatch their eggs.

\subsection{Mulberry Extract and Artificial Food}

Mulberry extract (ME) is in the form of powder obtained from Fisheries and Marine Biotechnology Laboratory Center for Research Hasanuddin University. $100 \mathrm{mg}$ extract is dissolved in $10 \mathrm{~mL}$ ethanol (p.a) $80 \%$. Extract solvent is then sprayed to the food made of commercial shrimp larvae. The food is air-dried to evaporate the ethanol before kept and used. The commercial artificial food (1) which is in the form of powder used for zoea contains at least $48 \%$ protein and $8 \%$ fat, while for megaloph, the commercial artificial food (2) is in the form of flake containing $48-53 \%$ protein and $3-5 \%$ fat.

\subsection{Larval Rearing}

The rearing is done over 19 days in a concrete tank with a volume of 1 ton with initial density of zoea- 1 at \pm 350.000 . Food containing mulberry extract is given on the eight day after the stocking, which is the time when larvae enter zoea-3. During the rearing, live food (rotifers and artemias nauplii) is still given based on the schedule (Table 1). Moreover, water exchange and aeration are performed to keep the oxygen content and to keep larvae away 
from gathering in certain spot. The placement of artificial seagrass in the tank as shelter is performed in the stage Zoea-4.

Table 1. Feeding regime used for culturing the different growth stages of blue swimming crabs in this study

\begin{tabular}{|c|c|c|c|c|c|}
\hline \multirow[t]{2}{*}{ Food } & \multicolumn{5}{|c|}{ Stage of the Blue Swimming Crab Larvae } \\
\hline & $\mathrm{Z}_{2}$ & $\mathrm{Z}_{3}$ & $\mathrm{Z}_{4}$ & M & $\mathrm{C}$ \\
\hline \multicolumn{6}{|l|}{ Rotifers } \\
\hline \multicolumn{6}{|l|}{ Artemias nauplii } \\
\hline \multicolumn{6}{|l|}{ Commercial artificial food 1} \\
\hline Commercial artificial food 2 & & & & & \\
\hline
\end{tabular}

Notes: Particulars: $\mathrm{Z}$ = zoea; $\mathrm{M}$ = megaloph; $\mathrm{C}=$ crab

\subsection{Experimental Design and Data Analysis}

This study is based on the complete random design with 4 treatments and 3 replicates (Gaspesz, 1991). The dose treatments of ME mixed in larval artificial food are: (A1) control (without ME in food), (A2) $1 \mathrm{mg} \mathrm{ME} \mathrm{/100} \mathrm{g} \mathrm{food,} \mathrm{(A3)} 2 \mathrm{mg} \mathrm{ME} \mathrm{/100} \mathrm{g} \mathrm{food,} \mathrm{and} \mathrm{(A4)} 4 \mathrm{mg}$ ME /100 g food. Data collected in this study are the survival rate of crab larvae which successfully metamorphose to the next stage, the rate of larval development, and factors causing mortality. The Survival rate (\%) of each larval stage is calculated based on the number of larvae which are successful to metamorphose to the next stage divided by the number of larvae in each of the beginning of the re-treatments. Larval development is determined based on the modification of Larval stage Index (LSI) of Redzuari et al. (2012) (Table 2). To calculate LSI and determine factors causing mortality, larvae are identified using dissecting microscope. Morphological characteristics of stadia refer to the instructions by Arshad et al, (2006) (Table 3), characteristics of molting syndrome follow the procedures introduced by Hamasaki et al., (2002), and cannibalism is indicated by an incomplete larval morphological condition.

An illustration of the identification of LSI is as follows: If there are 10 larvae in the sampling from each treatment, 7 of them are in the stage Zoea-2 and 3 others are in the stage Zoea-1, so the LSI is:

LSI $=[(2 \times 7)+(1 \times 3)] / 10=1.7 \sim 2.0$, meaning that the larvae is in the stage 2 


\section{Macrothink}

Table 2. Larval stage index (LSI)

\begin{tabular}{lll}
\hline Larvae Stage & LSI & Conclusion of LSI \\
\hline Zoea-1 $\left(\mathrm{Z}_{1}\right)$ & $1-1.5$ & 1 \\
Zoea-2 $\left(\mathrm{Z}_{2}\right)$ & $1.6-2.5$ & 2 \\
Zoea-3 $\left(\mathrm{Z}_{3}\right)$ & $2.6-3.5$ & 3 \\
Zoea-4 $\left(\mathrm{Z}_{4}\right)$ & $3.6-4.5$ & 4 \\
Megaloph $(\mathrm{M})$ & $4.6-5.5$ & 5 \\
Crab $(\mathrm{C})$ & $5.6-6.5$ & 6 \\
\hline
\end{tabular}

Table 3. Larval stages based on the morphological characteristics

\begin{tabular}{|c|c|}
\hline Larva Stages & Morphological characteristics \\
\hline Zoea-1 $\left(Z_{1}\right)$ & Eyes sessile, 5 segmented abdomen with a fork resembles a telson \\
\hline Zoea-2 $\left(\mathrm{Z}_{2}\right)$ & Eyes stalked, abdomen and telson are in similar condition with the ones in the previous stage \\
\hline Zoea-3 $\left(Z_{3}\right)$ & $\begin{array}{l}\text { Eyes stalked, } 6 \text { segmented abdomen, lateral spines on somites 3-5 longer, paired pleopod } \\
\text { buds at ventral posterior end of somites 2-5. Telson similar to that of previous stage }\end{array}$ \\
\hline Zoea-4 $\left(\mathrm{Z}_{4}\right)$ & $\begin{array}{l}\text { Eyes stalked, } 6 \text { segmented abdomen, pleopod buds well developed telson similar to that of } \\
\text { zoea-3 except for additional short seta on inner margin }\end{array}$ \\
\hline Megaloph (M) & $\begin{array}{l}\text { More like crabs than zoea, the carapace gets rounded according to its length, first pereiopod } \\
\text { appears in the tip of the upper arm, abdomen in the posterior is still long }\end{array}$ \\
\hline Crab (C) & Abdomen is folded under cephalotorax like in adult crabs \\
\hline
\end{tabular}

In this study, all results are presented in the average value. Data are analyzed by using Variant Analysis (ANOVA) to determine the differences among treatments. It is considered statistically significant if $\mathrm{P}<0.05$ (Gasperz, 1991).

\section{Results and Discussion}

\subsection{Survival Rate}

The results of this study showed that the mulberry extract (ME) through artificial feed larva greatly affect the survival rate of crab larvae. In Table 4 and 5, it appears that only the larva that received $4 \mathrm{mg}$ mulbery extract/100 g diet succesfully past five phase of larva turn up to crab phase. However, all of larva in control and a dose of $1 \mathrm{mg} / 100 \mathrm{~g}$ was death in zoea-3, while a dose of $2 \mathrm{mg} / 100 \mathrm{~g}$ death in zoea-4. This indicates that the response of larva to the mulberry extract was strongly influenced by the dose. 
Table 4. The survival rate of successfully metaphormed crab larvae in each dose of treatment on mulberry extract

\begin{tabular}{lllll}
\hline \multirow{2}{*}{ Larval } & \multicolumn{4}{c}{ Survival Rate (\%) } \\
\cline { 2 - 5 } & A1 & A2 & A3 & A4 \\
\hline $\mathrm{Z}_{1}-\mathrm{Z}_{2}$ & 17 & 19 & 21 & 26 \\
$\mathrm{Z}_{2}-\mathrm{Z}_{3}$ & 8 & 20 & 53 & 78 \\
$\mathrm{Z}_{3}-\mathrm{Z}_{4}$ & 0 & 0 & 5 & 9 \\
$\mathrm{Z}_{4}-\mathrm{M}$ & 0 & 0 & 0 & 15 \\
$\mathrm{M}-\mathrm{C}$ & 0 & 0 & 0 & 47 \\
\hline
\end{tabular}

Notes: $\mathrm{Z}$ = zoea; $\mathrm{M}$ = megaloph; $\mathrm{C}$ = crab; $\mathrm{A} 1=0 \mathrm{mg}$ mulberry extract $(\mathrm{EM}) / 100 \mathrm{~g}$ food; $\mathrm{A} 2$ = $1 \mathrm{mg} \mathrm{EM} ; \mathrm{A} 3$ = 2 mg EM; A4 = 4 mg EM.

Table 5. Larval Stage Index (LSI) of crabs given mulberry extract of different doses through the addition to the artificial food based on the rearing period

\begin{tabular}{lllllllllll}
\hline & \multicolumn{10}{c}{ Days to- } \\
\cline { 2 - 11 } Treatment & 1 & 3 & 5 & 7 & 9 & 11 & 13 & 15 & 17 & 19 \\
\hline A1 & 1.00 & 1.13 & 1.80 & 2.00 & 3.00 & & & & & \\
A2 & 1.00 & 1.00 & 1.65 & 2.00 & 2.75 & 3.00 & & & & \\
A3 & 1.00 & 1.00 & 1.20 & 2.14 & 3.55 & 4.00 & & & & \\
A4 & 1.00 & 1.11 & 1.39 & 2.10 & 3.74 & 4.00 & 4.74 & 4.90 & 5.37 & 6.00 \\
\hline
\end{tabular}

Notes: A1 = 0 mg mulberry extract $(\mathrm{EM}) / 100 \mathrm{~g}$ food ; A2 = $1 \mathrm{mg}$ EM; A3 = 2 mg EM; A4 = 4 mg EM.

An appropriate dose of mulberry extract will stimulate crabs to metamorphose and successfully pass molting process while low dose of mulberry extract will not be responded by larvae. Dorrington (1979) stated that appropriate dose of hormones would stimulate the activation of adenylate cyclase in cells so new products will be produced. Based on Turner and Bagnara (1976), hormones only stimulate actions but also inhibit them. There is a negative feedback mechanism in the hormonal work. High concentration of hormone in the circulation gives a sign for cells to do inhibitions to keep the balance (homeostatis), while low dose is not sufficient enough to stimulate actions.

\subsection{Larval Development}

Mulberry extract contains phytoecdysteroid, a compound which is analogous with molting hormone in crustaceans. Ecdysteroid, not only has a role as a molting hormone in arthropods, but also takes part as a regulator of other physiological functions such as growth, metamorphosis and reproduction (Gunamalai et al., 2003). Molting process starts when epidermal cells respond the hormonal change through the rate of protein synthesis (Meyer, 2007). Protein synthesis is the most basic growth process. If there is no massive protein production, growth process will not happen (Jobling et al., 2001). Protein takes an important role in the formation of new cells, including the formation of new cuticles.

Blue Swimming Crabs have four zoea stages and 1 megalophal stage. Zoea-1 (Z1) 
metamorphoses to Z2 and continues to Z4. Megaloph metamorphoses to first crab instar. The total time needed for the growth of zoeal stages to crab stage in this study is 17-19 days. It is longer than the total time of growth reported by Josileen and Menon (2004), which is 14-17 days and the one reported by Arshad et al. (2006), which is 14-19 days. However, it is faster than the duration of rearing from Z1 to crab which is 20 days as reported by Maheswarudu et al. (2008). This difference may caused by temperature difference and salinity of rearing media. Based on Arshad et al. (2006), salinity of 28-30 ppt and media temperature during the larval rearing of $26-27{ }^{\circ} \mathrm{C}$ lead to time needed to reach crab stage until for about 15-18 days. Josileen and Menon (2004) used salinity of $35 \pm 1$ ppt and temperature of $28 \pm 2^{\circ} \mathrm{C}$ during the rearing. Maheswarudu et al. (2008) reared the crab larvae at the temperature of $24-27^{\circ} \mathrm{C}$. In this study, media salinity ranges from 29 to33 ppt and the temperature is $26-31{ }^{\circ} \mathrm{C}$. According to Boyd (1990), crustaceans are poikilothermic, meaning that their body temperature is influenced by water temperature around them. It may be possible that certain species can tolerate wider range of temperature, but the temperature range for maximum growth is generally small.

The success of molting and certain stage change is surely not only influenced by molting hormones. Various other factors such as environment, nutrition, disease, and mutual interaction are major determinants whether a larva can pass a critical period or not. This is determined by larval resistance against various threats. The resistance of larva itself is influenced by nutritional status and genetic factors.

\subsection{Identifying the Cause of Daily Mortality}

In this study, there are four majors identified as the causes of mortality; they are: molting syndrome, fungal attacks, cannibalism, and morphological disorder (Figure 1).

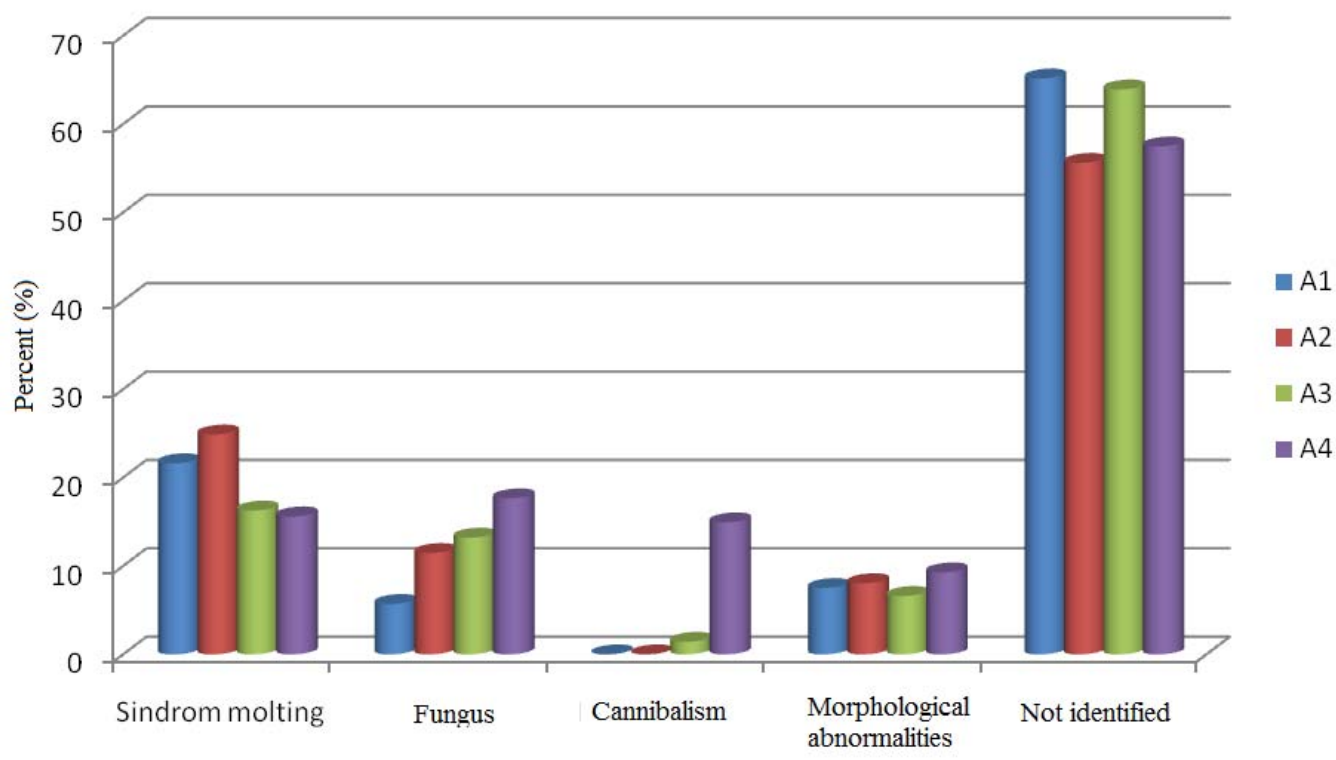

Figure 1. Mortality Percentage in Each Treatment due to Various Factors. A1 $=0 \mathrm{mg}$ Mulberry Extract (ME)/100 g food; A2 = $1 \mathrm{mg} \mathrm{ME;} \mathrm{A3} \mathrm{=} 2$ mg ME; A4 = 4 mg ME 


\section{Macrothink Institute ${ }^{\mathrm{TM}}$}

Unfortunately, the main cause of mortality $(55.61-65.17 \%)$ has not identified yet. It is said to be unidentified since in the morphological observation, the body of larvae remains normal and intact. This unidentified mortality happens in the initial stage and continually decreases along with the increase in the rearing time for all treatments (Figure 2, 3, 4, and 5). The mortality in the initial stage of rearing can be caused by the condition of the environment and quality of crab broodstock. In this study, the fluctuation of daily temperature reaches up to $3-5^{\circ} \mathrm{C}$. It is suspected that this kind of fluctuation influences the growth and mortality of larvae. Based on Boyd, (1990), if temperature suddenly changes by $3-4^{\circ} \mathrm{C}$, shock and mortality may occur.

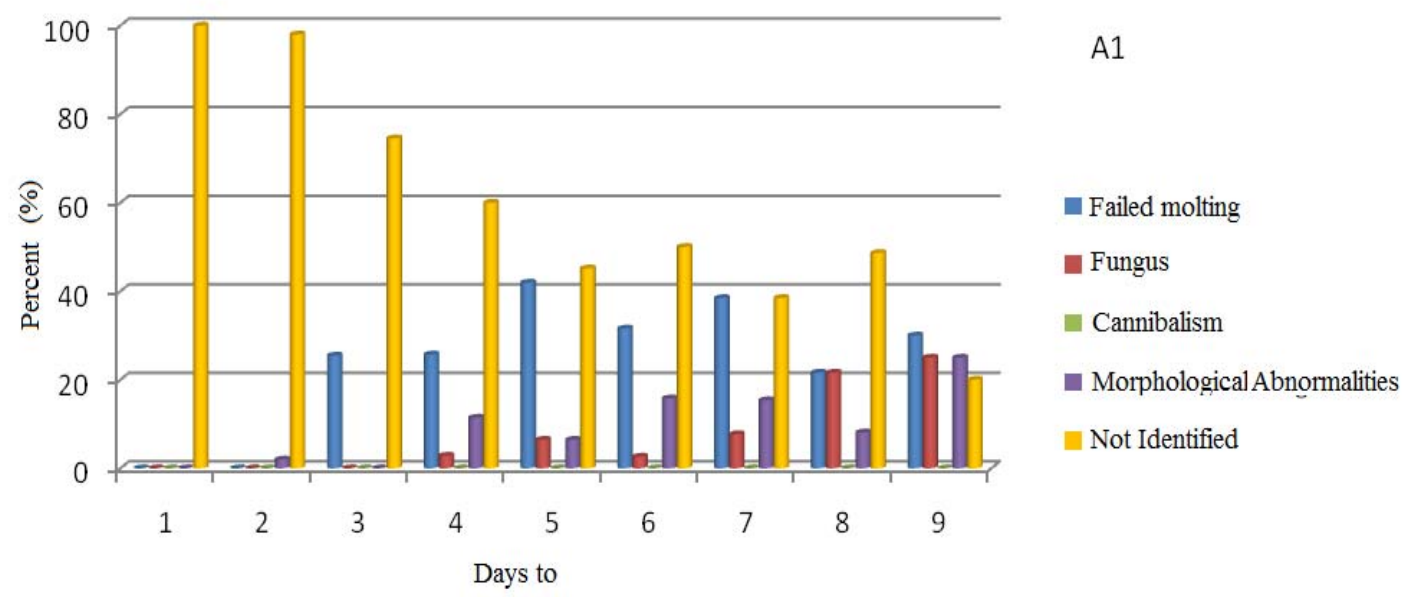

Figure 2. Identification on Daily Mortality Cause of Larvae in Treatment A1 (0 mg mulberry extract/100 g food)

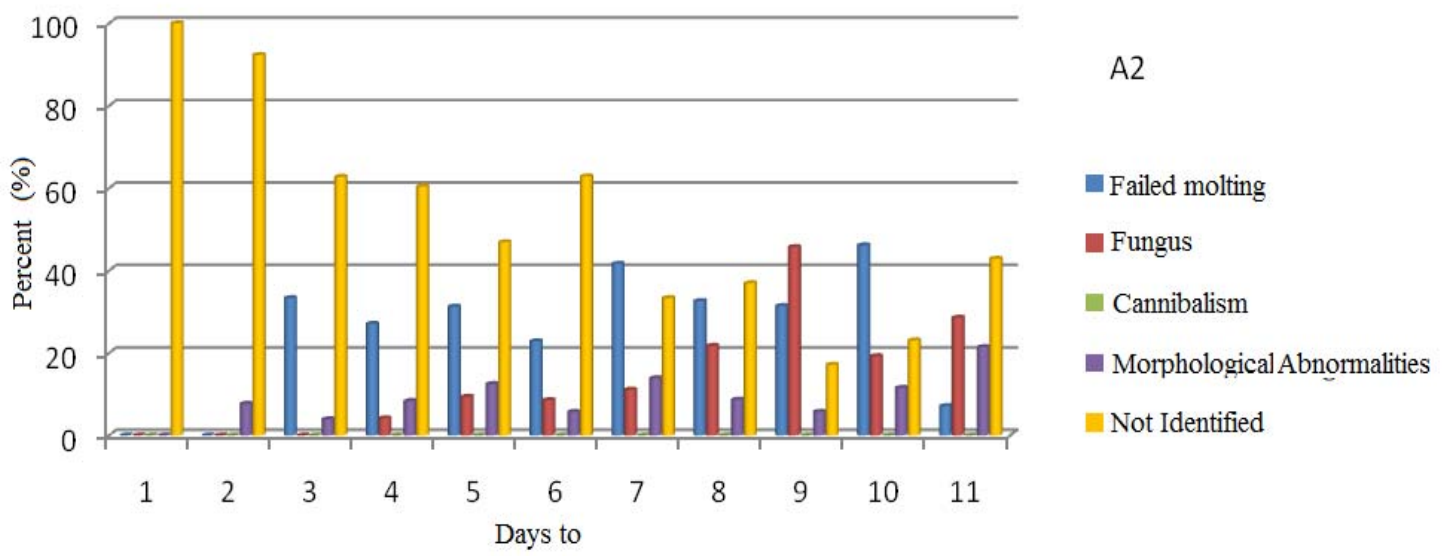

Figure 3. Identification on Daily Mortality Cause of Larvae in Treatment A2 (1 mg mulberry extract/100 g food) 


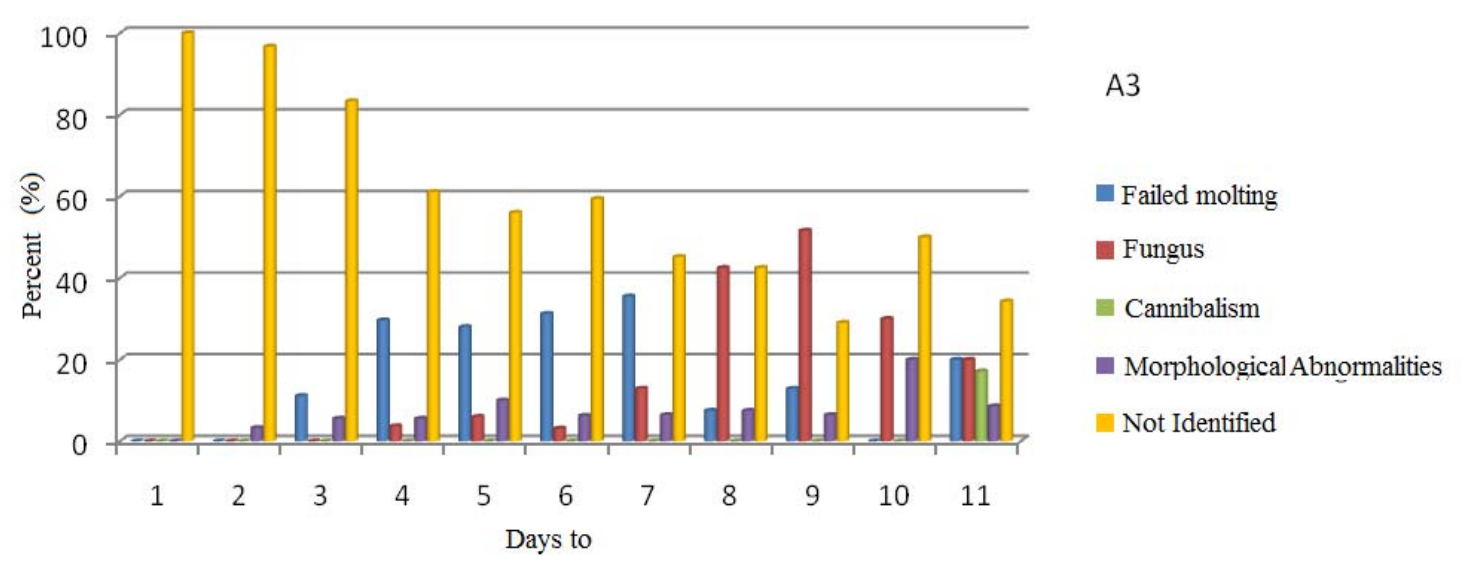

Figure 4. Identification on Daily Mortality Cause of Larvae in Treatment A3 (2 mg mulberry extract/100 g food)

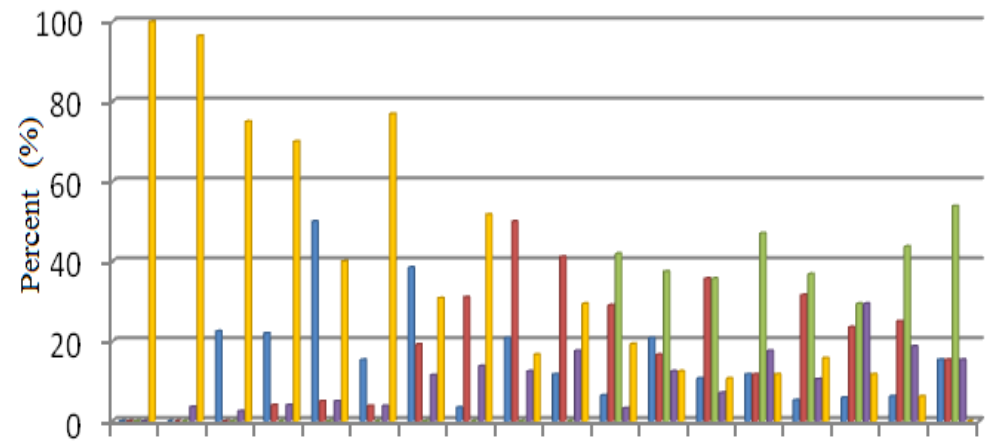

A4

Failed molting

Fungus

Cannibalism

Morphological Abnormalities

Not Identified

$\begin{array}{llllllllllllllllll}1 & 2 & 3 & 4 & 5 & 6 & 7 & 8 & 9 & 10 & 11 & 12 & 13 & 14 & 15 & 16 & 17 & 18\end{array}$

Days to

Figure 5. Identification on Daily Mortality Cause of Larvae in Treatment A4 (4 mg mulberry extract/100 g food)

The result of statistical analysis shows that the treatment of difference doses of ME in the artificial food of crab larvae has a significant effect towards mortality rate due to molting syndrome, fungal attacks, cannibalism $(\mathrm{P}<0.01)$, and significantly influenced morphological disorder $(\mathrm{P}<0.05)$. Conversely, treatment does not influence on unidentified larval mortality $(\mathrm{P}>0.05)$

The mortality due to the lowest molting syndrome in the treatment A3 and A4 shows that the given mulberry extract can be used by larvae and is effective enough to overcome molting syndrome. Molting syndrome significantly decreases in the treatment A3 and A4 especially after day-8, the day when artificial food containing mulberry extract is first given (Figure 2, 3, 4, 5). According to Thomton et al. (2006), molting syndrome experienced by crustaceans in the initial stage of larval stage is generally caused by insufficient supply of ekdisteroid needed for molting. 
However, data shown in Figure 1 explains that the higher of mulberry extract dose in food, cause higher mortality due to fungal attacks and cannibalism. Does mulberry extract stimulate the fungal growth and cannibalism? Figure 2, 3, 4, and 5, show that there is an indication that it is not mulberry extract which causes an increase in fungal attacks and cannibalism, but the rearing period which is longer in treatment A4. Figure 2, 3, 4 and 5 show good condition since fungi start to be indentified since day-4, but the intensity starts to increase since day-8 for all treatments. The rearing in treatment A is stopped in day-10 while in the treatment A2 and A3, it is stoppedin day-12 as all larvae are already died. Larvae in treatment A4 survive until they reach crab stage in day-19. Fungal attacks can be originated from water, food, or contaminated parents. Soundarapandian and Tamrehazhagan, (2009) stated that the quality of water and food are important criteria in the crab rearing. If both of them are not seriously taken care of, disease attacks might appear causing mortality to larvae.

The same thing happens in the case of cannibalism, since the treatment with the dose of $4 \mathrm{mg}$ mulberry extract/100 $\mathrm{g}$ food is the only treatment which is successful in entering megaloph and crab stage, so it also becomes the only treatment which mortality caused by cannibalsm is identified. Cannibalism increases in the stage of megaloph as claws in their bodiesare perfectly formed like in the crab stage. It will be worse since if molting does not happen simultaneously, the molting larvae will suffer from larvae which do not molt. Basically, cannibalism is the nature of crustaceans including crabs, but this nature must be controlled in cultural attempt. Marshall et al., (2005) explained that cannibalism can be caused by varied size of larvae and molting phase. The placement of many shelters can help reduce mortality rate caused by cannibalism.

Morphological disorder is also one of the factors causing larval mortality in this study even though the number is very small at about $7-9 \%$ of the total mortality in all treatments. Based on the analysis of statistics, it is shown that ME treatment has a significant influence $(\mathrm{P}<0.05)$ on the morphological disorder. This indication suggests that $\mathrm{ME}$ dosage may not be appropriate. Schmelz et al., (2002) and Soriano et al., (2004) stated that fitoekdisteroid compounds produced by plants cause abnormal molting in insects which attack plants, so they could not move, have lower attacks, have an abnormal growth, and are at risks of mortality. Besides, morphological disorder may also be caused by nutritional deficiency and genetic factors. This is based on the observation that before ME administration is conducted, mortality caused by morphological disorder has already happened.

\section{Conclusion}

Mulberry extract can be used to enrich artificial food in order to stimulate growth and metamorphosis and reduce mortality rate due to molting syndrome in crab larvae. However, further studies to determine the optimum dose of mulberry extract so molting and stage change will happen simultaneously, which further may reduce the mortality rate due to morphological disorder and cannibalism, are still needed. The enrichment of live food (rotifers and artemias nauplii) using ME to supply molting hormones in the stage Z1 and Z2 still need to be considered. Besides molting syndrome and cannibalism, mortality case due to fungal attacks, morphological disorder, and unidentified factors need special attention in the 
operation of crab rearing. Quality of water, food, and broodstock have to be improved to overcome those factors.

\section{Acknowledgment}

The researcher would like to give thanks to the Ministry of Education and Culture of Indonesian Republic for the funding through Grant for National Strategic Competitive Research.

\section{References}

Arshad, A., Efrizal, M. S., Kamaruddin, \& Saad, C. R. (2006). Study on fecundity, embryology and larval development of Blue Swimming Crab Portunus pelagicus (Linnaeus, 1758) under laboratory conditions. Research Journal of Fisheries and Hydrobiology, 1(1), 35-44.

Aslamyah, S., \& Fujaya, Y. (2010). Stimulation of Molting and Growth of Mangrove Crab (Scylla spp) trough Artificial Food made of Food Waste Enriched with Spinach Extract. Indonesian journal of marine science, 15(3), 170-178.

Azra, M. N., Safiah, J., Munafi, A. B. A., \& Ikhwanuddin, M. (2012). Effects of 20-Hydroxyecdysone on Early Larval Stages of Blue Swimming Crab's, Portunus pelagicus (Linnaeus, 1758). UMT 11th International Annual Symposium on Sustainability Science and Management 09th - 11th July 2012, Terengganu, Malaysia.

Boyd, C. E. (1990). Water Quality in Ponds for Aquaculture. Alabama: Birmingham Publishing Ca.

Dorrington, J. H. (1979). Pituitary and placental hormones. In C. R. Austin \& R. V. Short (Eds.), Reproduction in Mammals; 7 Mechanisms of hormone action. Cambridge: Cambridge University Press.

Feldman, J. I. G. (2009). Phytoecdysteroids. Understanding their anabolic activity. (Unpublished Doctoral Dissertation). The State University of New Jersey.

Fujaya, Y. (2011). Growth and molting of mud crab administered by different doses of vitomolt. Jurnal Akuakultur Indonesia, 10(1), 24-28.

Fujaya, Y., Aslamyah, S., \& Usman, Z. (2011). Molting response, growth, and mortality of mangrove crab (Scylla olivacea) supplemented with vitomolt via injection and artificial food. Indonesian journal of marine science, 16(4), 211-218.

Gaspesz, V. (1991). Metode Perancangan Percobaan untuk Ilmu-Ilmu Pertanian, Ilmu Teknik dan Biologi. Armico. Bandung. 472 hal.

Govindasamy, C., \& Srinivasan, R. (2012). Association of bioluminescent bacteria from blue swimmer crab Portunus pelagicus (Linneaus, 1758). Asian Pacific Journal of Tropical Disease, S699-S702. http://dx.doi.org/10.1016/S2222-1808(12)60246-1

Gunamalai, V. R., Kirubagaran, \& Subramoniam, T. (2004). Hormonal coordination of 
molting and female reproduction by ecdysteroids in the mole crab Emerita asiatica (Milne $\begin{array}{lllll}\text { Edwards). Gen. } \quad \text { Comp. } & \text { endocrinol, 138(2), }\end{array}$ http://dx.doi.org/10.1016/j.ygcen.2004.06.002

Hamasaki, K., Suprayudi, M. A., \& Takeuchi, T. (2002). Mass mortality during metamorphosis to megalops in the seed production of mud crab Scylla serrata (Crustacea, Decapoda, Portunidae). Fisheries Science, 68, 1226-1232. http://dx.doi.org/10.1046/j.1444-2906.2002.00559.x

Huberman. (2000). Shrimp endocrinology: a review. Aquaculture, 191, 191-208. http://dx.doi.org/10.1016/S0044-8486(00)00428-2

Ikhwanuddin, M., Azra, M. N., Yeong, Y. S., Munafi, A. B. A., \& Shabdin, M. L. (2012). Live foods for juveniles production of blue swimming crab, Portunus pelagicus (Linnaeus, 1766). Journal of Fisheries and Aquatic Science, 1-13.

Jobling, M., Boujard, T., \& Houlihan, D. (2001). Food Intake in Fish. Blackwell Science Ltd, A Blackwell Publishing Company.

Josileen, J., \& Menon, N. G. (2004). Larval stages of the blue swimmer crab, Portunus pelagicus (Linnaeus, 1758) (Decapoda, Brchyura). Crustaceana, 77(7), 785-803. http://dx.doi.org/10.1163/156854004774248681

Juwana, S., Ruyitno, Y. R., Alfianzah, \& Sujono. (2010). Utilization of Artemia Nauplii, Supplemented diet and commercial probiotic, for production of crab seed (Portunus pelagicus). Oseanologi dan Limnologi di Indonesia, 36(3), 259-279.

Lockwood, A. P. M. (1967). Aspect of The Physiology of Crustacea. San Fransisco: W.H.Freeman and Company.

Mahesa, R. W. (2010). Ekspor Rajungan Terancam Sertifikasi. Retrieved from: http://industri.kontan.co.id/news/ekspor-rajungan-terancam-sertifikasi-1

Maheswarudu, G., Jose, J., Nair, K. R. M., Arputharaj, M. R., \& Ramakrishna, A. (2008). Evaluation of the seed production and grow out culture of blue swimming crab Portunus pelagicus (Linnaeus, 1758) in India. Indian Journal of Marine Science, 37(3), 313-321.

Marshal, S., Warburton, K., Peterson, B., \& Mann, D. (2005). Cannibalism in juvenile blue swimmer crabs Portunus pelagicus (Linnaeus, 1766): effects of body size, moult stage and refuge availability. Applied Animal Behaviour Science, 90(1), 65-82. http://dx.doi.org/10.1016/j.applanim.2004.07.007

Meyer, J. R. (2007). Morphogenesis. Department of entomologi NC State University. Retrieved from www.morphogenesis .htm. DL 27 September 2007.

Nguku, E. K., Muli, E. M., \& Raina, S. K., (2007). Larvae, cocoon and post-cocoon characteristics of bombyx mori L. (lepidoptera:bombycidae) fed on mulberry leaves fortified with Kenyan royal jelly. J. Appl. Sci. Environ. Manage, 11(4), 85-89.

Redzuari, A., Azra, M. N., Abol-Munafi, A. B., Aizam, Z. A., Hii, Y. S., \& Ikhwanuddin, M. 
(2012). Effects of Feeding Regimes on Survival, Development and Growth of Blue Swimming Crab, Portunus pelagicus (Linnaeus, 1758) Larvae. World Applied Sciences Journal, 18(4), 472-478.

Samuel, N. J., Peyall, S., \& Thananjayan, A. (2011). Seed production of commercially valuable portunid crab Portunus sanguinolentus (Herbst). Euro. J. Exp. Bio., 1(2), 23-32.

Schmelz, E. A., Grebenok, R. J., Ohnmeiss, T. E., \& Bowers, W. S. (2002). Interaction between Spinacea oleracea and Bradysia impatiens: a role for phytoecdysteroids. Arch Insect Biochem Physiol, 51(4), 204-221. http://dx.doi.org/10.1002/arch.10062

Soriano, I., Riley, I., Potter, M., \& Bowers, W. (2004). Phytoecdysteroids: a novel defense against plant-parasitic nematodes. Journal of Chemical Ecology, 30, 1885-1899. http://dx.doi.org/10.1023/B:JOEC.0000045584.56515.11

Soundarapandian, P., Thamizhazhagan, E., \& Samuel, N. J. (2007). Seed Production of Commercially Important Blue Swimming Crab Portunus pelagicus (Linnaeus). Journal of Fisheries and Aquatic Science, 2, 302-309. http://dx.doi.org/10.3923/jfas.2007.302.309

Talpur, A. D., Memon, A. J., Khan, M. I., Ikhwanuddin, M., Daniel, M. M. D., \& Abol-Munafi, A. B. (2011a). A novel of gut pathogenic bacteria of Blue Swimming Crab Portunus pelagicus (Linneaus, 1958) and pathogenicity of Vibrio harveyi a transmission agent in larval culture under hatchery condition. Research Journal of Applied Sciences, 6(2), 116-127. http://dx.doi.org/10.3923/rjasci.2011.116.127

Talpur, A. D., Memon, A. J., Khan, M. I., Ikhwanuddin, M., Daniel, M. M. D., \& Abol-Munafi, A. B. (2011b). Pathogenicity and antibiotic sensitivity of pathogenic flora associated with the gut of Blue Swimming Crab Portunus pelagicus (Linneaus, 1958). Journal of Animal and Veterinary Advances, 10(16), 2106-2119. http://dx.doi.org/10.3923/javaa.2011.2106.2119

Thompton, J. D., Tamone, S. L., \& Atkinson, S. (2006). Circulating ecdysteroid concentration in Alaskan Dungesess crab (Cancer magister). Journal of crustacean biology, 26(2), 176-181. http://dx.doi.org/10.1651/C-2625.1

Turner, C. D., \& Bagnara, J. T. (1976). Endokrinologi Umum. Jogyakarta: Airlangga University Press.

Zmora, O., Findiesen, A., Stubblefield, J., Frenkel, V., \& Zohar, Y. (2005). Large-scale juvenile production of the blue crab Callinectes sapidus. Aquaculture, 244, 129-139. http://dx.doi.org/10.1016/j.aquaculture.2004.11.012

\section{Copyright Disclaimer}

Copyright reserved by the author(s).

This article is an open-access article distributed under the terms and conditions of the Creative Commons Attribution license (http://creativecommons.org/licenses/by/3.0/). 